\title{
The Development of Innovative Learning Material With Problem Based Approach to Improve Students Competence in The Teaching of Physical Chemistry
}

\author{
Ani Sutiani \\ Chemistry Education of Graduate Study Program \\ Universitas Negeri Medan \\ Medan, Indonesia \\ Corresponding author: asr.sutiani@gmail.com \\ Albinus Silalahi \\ Chemistry Education of Graduate Study Program \\ Universitas Negeri Medan \\ Medan, Indonesia \\ Manihar Situmorang \\ Chemistry Education of Graduate Study Program \\ Universitas Negeri Medan \\ Medan, Indonesia
}

\begin{abstract}
Innovation learning material with problem based approach is beliefed to be applicable to improve students' competence as required by the Implementation of Indonesian National Qualifications Framework (Kerangka Kualifikasi Nasional Indonesia, KKNI) curriculum on the teaching of Physical Chemistry. This research aimed to develop an innovative learning material with problem based approach to be used as a learning resources to improve students competence on Physical Chemistry. The research is conducted in Department of Chemistry Universitas Negeri Medan. The steps to be followed are including enriching of chemistry learning material on Physical Chemistry, setting the chemistry material in problem based approach, integration of laboratory experiment and learning activities, and implementation of innovative learning material in the class. The results obtained in the study has provided a standard and innovative learning package that are designed in problem based approach has been developed successfully that is suited to the KKNI curriculum. The problem based approach provided in the learning material is found to be able to guide the students to learn independently in Physical Chemistry. The students are found be able to construct the relationship between chemistry concept with daily life application. Integration of multimedia in the learning material has motivated the students to learn the topics and Physical Chemistry easy to learn. Innovative learning material has been proven to be able to improve students' competence since they are forced to do the work independently. The facility available in a learning package has adequate to guide the student for self learning.
\end{abstract}

Keywords- Innovative, Learning Material, Problem based, Physical Chemistry

\section{INTRODUCTION}

National education in Indonesia has been set as one of the national development sectors to educate the life of the nation has a vision in the realization of an educational system as a powerful and authoritative social institution to empower all Indonesian citizens to become qualified human beings, so as to be able and proactive to answer the challenges of the everchanging era. The current development of science and technology has led to the enactment of Indonesian National Qualification Framework (KKNI) Curriculum in universities that aim to develop students' potential optimally. Therefore, to improve the students 'competence in the field of knowledge, attitude and skills, it is necessary for students to learn independently and continuously [1,2] Additionally it is necessary the relevant learning materials and easily understood by students in accordance with the applicable curriculum demands. Good learning materials should be able to present the subject matter in accordance with the demands of the curriculum, the development of science and technology, and can bridge learning in order to achieve the established competencies [3]. In addition, innovation in learning materials should provide opportunities in the formation of student characters to be skilled at building their knowledge capacity independently through high-level thinking skills, such as critical thinking. creative and decision making, as well as solving problems $[2,4]$. Critical thinking is thought to help in solving problems and making decisions, whereas problem solving is the process by which individuals try to overcome 
the problems faced to achieve goals. It relates to how we think rather than what we think [5].

Physical Chemistry course is one of the compulsory subjects in Chemistry Department. The studies discussed in Chemical Physics include Chemical Kinetics and Equilibrium. The number of concepts involving the calculation and understanding of diagrams or curves in Physical Chemistry material causes the need for students to learn about critical thinking and problem solving skills so as to acquire essential knowledge and concepts from the subject matter [6]. In addition, the learning model should be student-centered, so that students are given the opportunity to work autonomously to construct their learning methods, and the lecturer only is functioned as a motivator and facilitator [7]. Physical chemistry learning has been given both in the form of theory and practicum, but it has not been fully integrated, so it has not been able to make the students master the competence set, especially the low-ability students, besides the highly skilled students also have not obtained optimal learning service [6]. Therefore, in an effort to improve students' competence in Physical Chemistry course, it needs learning materials with problem based approach, known as Problem Based Learning (PBL).

The students involved in a PBL is encouraged to become independent learner. The PBL approach are empowering the students to conduct research, integrating theory and practice, and applying knowledge and developing feasible solutions for problem solving, and preparing individuals for self-sustaining and self-sustaining learning [2,7]. The PBL is a pedagogical approach based on recent advances in cognitive science research in the learning process, which is organized as a collaborative problem-solving activity, and it provides a context for learning and discovery [8]. This approach lead the students learn in the context of problems to solve, so that the responsibility for learning is in the students, not within the facilitator [9]. There are 5 stages to be followed in the PBL process, they are introduction, inquiry, self-study, hypothesis review, and evaluation. This study aims to produce innovative learning materials using problem-based approaches to improve student competence in physical chemistry course.

\section{LITERATURE REVIEW}

\section{A. Innovative Learning Material}

Learning materials are part of a learning resource that contains materials or lecture materials used by students and lecturers in the lecture process. Learning materials have a systematic structure and sequence, explain the objectives to be achieved, and help students to be able to learn independently, so that the accumulative able to master the competence as a whole and integrated.

Innovative learning materials are learning materials that are more flexible in accordance with the needs of students. Flexibility considers and takes into account various aspects that include student characteristics including intellectual, emotional and spiritual abilities as well as obstacles in learning [10]. Innovative learning materials should provide instruction and practice and feedback, so it is interactive, which allows students to learn the material presented. To develop innovative learning materials, the lecturers must understand how far the interests and talents of students, so that students are motivated to learn independently so as to be able to control the competencies that have been determined.

\section{B. Problem Based Approach}

The general approach to learning can be interpreted as a perspective (point of view) theory that might be used as a basis in selecting models, methods and techniques of learning. Learning approach is a process or deeds used by lecturers to present the lesson material and serve as a starting point or point of view of the learning process [11]. The paradigm shift of learning focus from teacher centered learning to learning centered on students (student center learning) is one of the efforts to improve the quality of process and learning outcomes [12]. One of the appropriate approaches is the problem-based approach, which is an approach that empowers students to undertake research, integrate theory and practice, and apply knowledge and ability to develop viable solutions to problem solving, and be able to prepare individual selfsustaining learners $[2,13]$.

A problem-based approach is learning that uses problems as a focus for developing problem-solving skills, materials and self-regulation $[8,14]$. This means that PBL is a learning model based on the principle of using the problem as a starting point and integration of new knowledge. In problem-based learning, problem-solving is defined as a process or attempt to get a real-time task and situation settlement as a problem by using known rules [15]. The PBL process begins with an unstructured problem and the student must be able to resolve the issue. After understanding the problem, the student will identify the information already known and the information needed to be learned in order to find the solution of the problem. There are three main components required in PBL, students as learners, instructors or lecturers as tutors, and problems such as context [5,16]. PBL uses real-world problems as a context for students to learn about critical thinking and stimulate high-level thinking in problem-oriented situations, and to acquire essential knowledge and concepts from instructional materials [17].

\section{RESEARCH METHODOLOGY}

\section{A. Research Design}

Research conducted is Research and Development ( $\mathrm{R} \&$ D) by the development of an innovative learning material with problem based approach to be used as a learning resources to improve students competence on Physical Chemistry. The development is conducted to provide chemistry learning material in problem based approach on Physical Chemistry as models to be used in the class to improve students competence on Physical Chemistry [18,19]. An innovative learning materials with problem-based approach for Physical Chemistry course are dealing with enriching chemistry learning material and combining the subject with problem for Physical Chemistry topic of kinetics, chemical equilibrium and phase equilibrium and its application in the science of daily life. The stages of the research are: (1) development of 
learning materials through the enrichment of materials based on basic knowledge, (2) preparation of standard problem and evaluation grids, (3) integration of package of practicum activities and learning activities, (4) feasibility study of learning materials, and (5) implementation of learning materials [20]. The research instruments composed consist of (1) assessment sheets (Validation) of textbook adapted from National Education Standards Agency (BSNP) [21], and (2) a test instrument to measure student learning outcomes of course materials provided in the learning process.

\section{B. Design of Learning Material}

The development of innovative learning materials with problem-based approaches conducted in this study is divided into 3 (three) stages. The first stage is the needs analysis phase. At this stage will be identification and analysis of Physical Chemistry material characteristics based on basic knowledge [20]. The second stage is the design stage of learning materials products. Activities in this stage is the preparation of learning materials through description of material based on the Curriculum of KKNI, the concept of delivery and organizing the material with a problem-based approach, the type of task, worksheet and practice questions. The third stage is the validation and analysis stage. This stage is a series of product development assessment stage. Thus validation results was analyzed and made revisions based on input or suggestions so that the learning materials developed into products that were suitable for use. The tool of the assessment of learning materials consisted of a suggestion sheet and comments and questionnaires in the form of written questions that were used to obtain information from respondents, in the form of assessment form of the reviewer. The instrument of feasibility of learning materials was obtained by using questionaire with the questions are raised in multiple choice options, starting from strong opinion with positive response of very good (score 5), down to a very low opinion with negative view of very poor/bad (score 1) [22]

\section{Learning Material Implementation}

Implementation of learning materials with problem-based approach in the learning process aimed to obtain the quantitative data research from the results of students learning. Thus, learning result of data obtained through the implementation of learning materials in the process of learning in Physical Chemistry courses were tested on the students of chemistry education program Faculty of Mathematics and Sciences of State University of Medan in academic year 2016/2017. For the experimental class, learning process was done with the instructional materials that already prepared, while for the control group, learning was through without using the instructional materials that prepared. Before the learning process begins, pretest was administered and after the learning process done the postest was given. Analysis of learning outcomes was done by pretest-postest of control group design technique

\section{RESULT AND DISCUSSION}

The research undertaken was basically to develop learning materials through the enrichment of materials, along with the preparation of a grid of standard practice and evaluation. The results of learning materials development were tested based on the feasibility test and the implementation of learning materials to improve students' competence in Physical Chemistry course in the university. The study material in Physical Chemistry conducted in this research consists of 3 (three) parts, they are chemical kinetics, chemical equilibrium and phase equilibrium. The first step in this research was the revision of material identification based on basic knowledge, consisting of chapter / sub-chapter, basic competency, learning output and learning outcomes and learning method [20]. The next step of the instructional description followed by the analysis of learning materials. Learning material descriptions were developed through material enrichment, practice questions, the integration of systematic and structured package of practicum and evaluation activities. The analysis of learning materials was based on the validation result done by the KDBK of Physical chemistry lecturer by using the instrument in the form of validation sheet of learning materials. The components of the validated learning material include several things: (1) the content feasibility component, (2) the language component, and (3) the component of the serving technique, and (4) the component of the graphic [21]. Learning outcomes are analyzed based on initial ability (pretest) and end-ability (posttest).

\section{A. Learning Material Description}

The instructional materials are based on the competence that must be achieved in Physical Chemistry learning in accordance with the KKNI curriculum requirements applicable in the educational program of Chemistry of Faculty of Mathematics and Sciences State University of Medan. The learning materials were developed through material enrichment, the preparation of the standard training and evaluation grid, and the integration of the practical activity and learning activities, structured in a systematic and structured way to support the theory of Physical Chemistry. Inside the material was equipped with contextual examples, drawings, and examples of problems and solutions that were applied in everyday life. In addition, there was provided a search link address which could be used as an additional reference. In general, the composed learning materials are summarized in Table I.

TABLE I. MATERIAL DESCRIPTION OF PHYSICAL CHEMISTRY

\begin{tabular}{|c|c|l|}
\hline \multirow{2}{*}{ No } & \multicolumn{2}{|c|}{ Material Desciption } \\
\cline { 2 - 3 } & Subject & \multicolumn{1}{c|}{ Description Subject } \\
\hline \multirow{2}{*}{1} & Introduction & $\begin{array}{l}\text { Presented general material descriptions, } \\
\text { prerequisites, instructional use of materials, } \\
\text { expected competencies and concept maps for } \\
\text { each subject }\end{array}$ \\
\hline 2 & $\begin{array}{l}\text { Chemical } \\
\text { Kinetic }\end{array}$ & $\begin{array}{l}\text { Enrichment of chemical kinetics materials, } \\
\text { integration of PBL, demonstration activities, }\end{array}$ \\
\hline
\end{tabular}




\begin{tabular}{|c|c|c|}
\hline \multirow{2}{*}{ No } & \multicolumn{2}{|r|}{ Material Desciption } \\
\hline & Subject & Description Subject \\
\hline & & $\begin{array}{l}\text { animation and ppt media settings, laboratory } \\
\text { activities, presentation of experimental data for } \\
\text { analysis, examples of various forms of } \\
\text { integration, exercises and examples of } \\
\text { applications in everyday life. }\end{array}$ \\
\hline 3 & $\begin{array}{l}\text { Chemical } \\
\text { Equilibrium }\end{array}$ & $\begin{array}{l}\text { Enrichment of learning materials, integration } \\
\text { of PBL for open system disclosure and } \\
\text { linkages to free energy changes, examples of } \\
\text { equation related cases of extent of reaction and } \\
\text { reaction isotherms, ppt media settings, and } \\
\text { presentation of sample questions and exercises. } \\
\text { Integration of laboratory activities, and } \\
\text { example of the concept of equilibrium shift } \\
\text { and relation to K. }\end{array}$ \\
\hline 4 & $\begin{array}{l}\text { Phase } \\
\text { Equilibrium }\end{array}$ & $\begin{array}{l}\text { Enrichment of phase equilibrium learning } \\
\text { materials, integration of PB, analysis of diary, } \\
\text { binary and ternary system phase models, TX } \\
\text { and PX diagrams, cases of eutectic, congruent } \\
\text { and incongruent systems, integration of } \\
\text { laboratory activities in the form of case studies } \\
\text { in daily life, the presentation of the decline of } \\
\text { equations in the form of sample questions and } \\
\text { exercises with examples in life and discussion. }\end{array}$ \\
\hline
\end{tabular}

\section{B. Learning Material Validation}

After the preparation of learning materials has completed, then the review of learning materials with the results of the validation was presented in Table II. Validation was done by lecturer of KDBK Physical chemistry by using instrument in the form of validation sheet of learning materials. The components of the validated learning materials include several things, (1) the content feasibility component, (2) the language component, and (3) the components of the presentation technique, and (4) the feasibility component of graphic. From the results of the analysis of learning materials, it could be seen that the validators provided a good category assessment of the compiled learning material shown by the average score of all components is average 4.15 (It categorised as very good)

TABLE II. RESPONDENTS OPINION TO THE DEVELOPED LEARNING MATERIAL OF PHYSICAL CHEMISTRY

\begin{tabular}{|c|l|c|l|}
\hline \multirow{2}{*}{ No } & \multicolumn{3}{|c|}{ Description Criteria of Innovative Learning Material } \\
\cline { 2 - 4 } & $\begin{array}{c}\text { Assessment } \\
\text { Components }\end{array}$ & Score & \multicolumn{1}{c|}{ Range Criteria } \\
\hline 1 & Content & 3.89 & $\begin{array}{l}\text { Very good and unnecessary } \\
\text { to be revised }\end{array}$ \\
\hline 2 & Language & 4.25 & $\begin{array}{l}\text { Very good and unnecessary } \\
\text { to be revised }\end{array}$ \\
\hline 3 & $\begin{array}{l}\text { Technique of } \\
\text { Presentation }\end{array}$ & 4.50 & $\begin{array}{l}\text { Very good and unnecessary } \\
\text { to be revised }\end{array}$ \\
\hline 4 & Graphic & 3,96 & $\begin{array}{l}\text { Very good and unnecessary } \\
\text { to be revised }\end{array}$ \\
\hline \multicolumn{2}{|c|}{ Average } & 4.15 & Very good \\
\hline
\end{tabular}

Based on the assessment score in the learning material components, in which the respondents gave very positive opinion (average 4.15) that were assigned to be very good $[3,18]$. The results in the learning package has met the standard requirements given by BSNP criteria in parameters of the content, language, technique of presentation, and graphic [22]. This means that the instructional materials were suitable to be used for the study of Physical Chemistry materials because they fell into the valid criteria according to BSNP standard and is ready to be implemented in the teaching and learning activities.

\section{Learning Outcome}

A set of developed learning material in PBL was implemented in the class for experimental class and existing learning was utilized in a control class. Pretests is carried out for both class before teaching and learning activities are being started, and followed the posttest after the teaching treatments. The result of pretest is needed to investigate the students' early ability and posttest result aimed to know the students learning result of each sample class. Learning result on the students performance from pretest and posttest is presented in Table III.

TABLE III. PRE-TEST AND POST -TEST SCORES OF PHYSICS CHEMISTRY

\begin{tabular}{|l|c|c|}
\hline \multirow{2}{*}{$\begin{array}{c}\text { Treatment } \\
\text { Classs }\end{array}$} & \multicolumn{2}{|c|}{$\begin{array}{c}\text { Average learning outcome (Score) } \text { in } \\
\text { Evaluation Test }\end{array}$} \\
\cline { 2 - 3 } & Pret Test & Post Test \\
\hline $\begin{array}{l}\text { Experimental } \\
\text { Class }\end{array}$ & $29.64 \pm 5.19$ & $89.97 \pm 7.56$ \\
\hline Control Class & $31.21 \pm 6.07$ & $80.42 \pm 4.23$ \\
\hline
\end{tabular}

The results on students achievement in Table III shows that before the learning was done, the students' in experimental and control class are having inadequate knowledge in Physical Chemistry topic, those are viewed from low score obtained in pretest for both for control group (31.21 \pm 6.07$)$ and experiment group (29.64 \pm 7.28$)$. Evaluation by using $t$-test showed that the two sample classes were not significantly different $\left(\mathrm{t}_{\text {count }} 0.982<\mathrm{t}_{\text {table }} 1.695\right)$. This means that all students in experimental and control class are having initial relatively same ability to solve Physical Chemistry evaluation test. After learning activities have been carried out, the students ability to solve Physical Chemistry evaluation test have been demonstrated as presented in Table III. All students improve their ability in Physical Chemistry course for both classes and the students achievements are significantly increased compared to pretest result. The learning result of experimental class students that used learning materials with problem based approach $(89.97 \pm 7.56)$ was higher than that obtained in control class learning result $(80.42 \pm 4.23)$. The $t_{\text {test }}$ results showed that the two sample classes were significantly different $\left(t_{\text {count }} 2,364>t_{\text {table }} 1,695\right)$. Based on the data achieved by the students, it could be stated that the difference of Physical Chemistry study result between the experimental class and the control class was caused by the use of learning materials with problem based approach in learning. This is because the learning activities undertaken were able to develop problem-solving skills and motivated students to do self-study [13,23] and facilitates students in learning the material presented, so as to improve students' competence. 


\section{CONCLUSION}

An innovative learning material with problem-based approach has been develop suited to KKNI curriculum and has been used as a learning resources to improve students competence on Physical Chemistry. The learning packages has been enrich with standard chemistry subjects and equipped with adequate instruction to be followed for PBL learning. The PBL activities in the learning material led students to do self-study and motivate themselves to master the topic. The learning activities in the PBL has bring the students to make a link of chemistry concept and theory into everyday life. Implementation of innovative learning materials in the class has proven that Physical Chemistry course with PBL becomes easy to learn. Learning result has showed that students achievement in experimental class with PBL $(89.97 \pm 7.56)$ was higher than that obtained in control class $(80.42 \pm 4.23)$, and both class are significantly different $\left(\mathrm{t}_{\text {count }} 2.364>\mathrm{t}_{\text {table }} 1.695\right)$.

\section{ACKNOWLEDGEMENTS}

This work was supported by Directorate Research and Community Service, Directorate General Strengthen Research and Development, Ministry of Research, Technology and Higher Education of the Republic of Indonesia, Under Penelitian Produk Terapan, Financial Year 2017, Contract No.045A/UN33.8/LL/2017

\section{REFERENCES}

[1] G. Tsapartis, U. Zoller, "Evaluation of Higher vs Lowerorder Cognitive Skills-Type Examination in Chemistry : Implications for University inclass Assessment and Examination", U.Chem.Ed. Vol.7, pp. 50-57, 2003.

[2] S. Temel, "The effects of problem-based learning on pre-service teachers : critical thinking dispositions and perceptions of problemsolving ability", South African Journal of Education, Vol. 34(1), 2014.

[3] M. Situmorang, "Pengembangan buku ajar kimia melalui inovasi pembelajaran dan integrasi pendidikan karakter untuk meningkatkan hasil belajar mahasiswa", Prosiding semirata FMIPA, Lampung, pp.237245, Mei 2013

[4] M.O. Abanikannda, "Influence Of Problem-Based Learning In Chemistry On Academic Achievement Of High School Students In Osun State Nigeria", International Journal of Education, Learning and Development, 4(3), pp.55-63, 2016.

[5] I. Bilgin, E. Senocak, and M. Sozbilir, "The effects of Problem-Based Learning Instruction on University Students Performance of Conceptual and Quantitative Problems in Gas Concepts", Europe Journal of mathematics, sains and technology education, 5(2), pp. 153-164, 2009..

[6] A. Sutiani, Zainuddin, \& A.W. Nugraha., "Penerapan Model Pembelajaran ATI dan Keterampilan Proses Pada Mata Kuliah Kimia Fisika II, Jurnal Pendidikan Kimia Program Pascasarjana Unimed. 3 (2). Pp. 12-20, 2011
[7] I. Chagas, I., C.Faria, D. Mourato, G. Pereira, G. \& A. Santos.. "Problem based learning in an online course of health education. European Journal of Open, Distance and E-Learning”, 2012 Retrieved from http://www.eurodl.org/index.php?article $=505$.

[8] K.B. Hartman, C.R. Moberg, and J.MLambert, J.M., "Effectiveness of problem-based learning in introductory business courses", Journal of Instructional Pedagogies, pp. 1- 13, 2013

[9] H. Jeong So, Kim, "Learning about Problem Based Learning : Student Teachers Integrating Technology, Pedagogy and Content Knowledge", Australasian Jornal of Educational Technology. 25 (1), pp. 101-116, 2009.

[10] M. Sitorus, A. Sudrajat, M. Lestari, "Pengembangan bahan ajar inovatif dan interaktif melalui pendekatan saintifik pada materi Redoks dan Elektrokimia", J. Pendidikan Kimia, Unimed, Vol. 7 No.2, pp. 61-71, Agustus 2015

[11] Y. Riyanto, "Paradigma Baru Pembelajaran : Sebagai Referensi bagi Pendidik dalam Implementasi yang Efektif dan Berkualitas. Kencana. Jakarta, 2010

[12] W. Sanjaya, "Strategi Pembelajaran Berorientasi Standar Proses Pendidikan", Kencana. Jakarta, 2009.

[13] C.Tosun, E. Senocak, "The Effects of Problem-Based Learning on Metacognitive Awareness and Attitudes toward Chemistry of Prospective Teachers with Different Academic Backgrounds", Australian Journal of Teacher Education., 38(3), 2013

[14] C.Hsieh, \& L.Knight, "Problem-based learning for engineering students An evidence-based comparative study. The Journal of Academic Librarianship, 34(1), pp. 25-30, 2008.

[15] O.C.Kelly, O.E. Finlayson, "Providing solutions through problem-based learning for the undergraduate 1st year chemistry laboratory", Chemistry Education Research and Practice. 8(3), pp. 347-361, 2007.

[16] M. Carrió, P.Larramona, J.Baños, \& J.Pérez, "The effectiveness of the hybrid problem-based learning approach in the teaching of biology: A comparison with lecture-based learning", Journal of Biological Education, 45(4), pp. 229-235, 2011

[17] A. Trauth-Nare, G.Buck, "Assessment "for" learning: Using formative assessment in problem and project based learning environments.", Active Learning in Higher Education, 14(2), pp. 109-122, 2011

[18] D. Woods, "PBL: An evaluation of the effectiveness of authentic problem-based learning (aPBL). Chemical Engineering Education, 46(2), pp. 135-14, 2012.

[19] Sugiyono, "Metode Penelitian Kuantitatif Kualitatif dan R\&D. Bandung. Alfabeta, 2011.

[20] A. Sutiani, Nurmalis, R. Nauli, "Pengembangan Model Pembelajaran Berbasis Masalah untuk meningkatkan kompetensi mahasiswa pada materi kesetimbangan fasa, Prosiding Semirata, pp.1829-1835. Mei 2016.

[21] BSNP. Kriteria Penilaian Buku. Depdiknas. Jakarta. 2006.

[22] M. Situmorang, M. Sitorus, W. Hutabarat, and, Z. Situmorang, "The Development of Innovative Chemistry Learning Material For Bilingua Senior High School Students in Indonesia", International Educational Studies 8(10), pp. 72-85, 2015.

[23] Sudarman, "Problem Based Learning: Suatu Model Pembelajaran untuk Mengembangkan dan Meningkatkan Kemampuan Memecahkan Masalah, Jurnal Pendidikan Inovatif. 2 (2). hal. 68-73, 2007. 